Pratami, A.

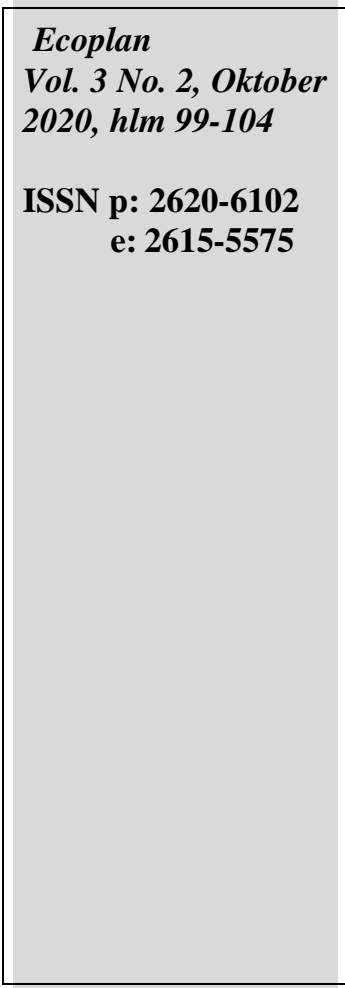

\title{
Dampak Inflasi dan Dana Pihak Ketiga terhadap Pembiayaan dengan Moderasi Pertumbuhan Ekonomi
}

\author{
Arifa Pratami \\ Universitas Islam Sumatera Utara \\ pratamiarifa@gmail.com
}

Abstract - The study aims to analyze the impact of inflation and third-party funds on financing by making economic growth a moderating variable. The course uses secondary monthly-form data from January 2010 to December 2017 with Sharia banking objects. The data analysis technique used is the Error Correction Model (ECM) analysis. The study results found that first, inflation does not have a significant effect on financing in Islamic banking either directly or with the moderating variable of economic growth. Second, Third Party Funds (TPF) does not have a significant direct effect on financing. In contrast, with the moderating variable of economic growth, it is found that economic growth can moderate the influence of Third Party Funds (TPF) on financing in a negative direction. This study provides a recommendation that Islamic banking continues to increase the distribution of Third Party Funds (TPF) in the real sector while still utilizing short-term investment financing instruments in the form of Bank Indonesia Syariah Certificates (SBIS) to increase the level of bank profitability.

Keywords: Sharia Banking, Inflation, Third-Party Funding, Economic Growth

\section{Dampak Inflasi dan Dana Pihak Ketiga terhadap Pembiayaan dengan Moderasi Pertumbuhan Ekonomi}

\begin{abstract}
Abstrak- Penelitian ini bertujuan untuk menganalisis dampak inflasi dan Dana Pihak Ketiga terhadap pembiayaan dengan menjadikan pertumbuhan ekonomi sebagai variabel moderating. Penelitian ini menggunakan data sekunder berbentuk bulanan dari periode Januari 2010 sampai dengan Desember 2017 dengan objek perbankan syariah. Teknik analisis data yang digunakan yaitu analisis Error Correction Model (ECM). Hasil penelitian menemukan bahwa pertama, Inflasi tidak memiliki pengaruh yang signifikan terhadap pembiayaan pada perbankan syariah baik secara langsung maupun dengan adanya variabel moderasi pertumbuhan ekonomi. Kedua, Dana Pihak Ketiga (DPK) tidak memiliki pengaruh signifikan secara langsung terhadap pembiayaan, sedangkan dengan adanya variabel moderasi pertumbuhan ekonomi, ditemukan bahwa pertumbuhan ekonomi mampu memoderasi pengaruh yang diberikan Dana Pihak Ketiga (DPK) terhadap pembiayaan dengan arah yang negatif. Rekomendasi yang dapat diberikan yaitu diharapkan perbankan syariah tetap meningkatkan penyaluran Dana Pihak Ketiga (DPK) di sektor rill disamping tetap memanfaatkan instrument pembiayaan investasi jangka pendek berupa Sertifikat Bank Indonesia Syariah (SBIS), guna meningkatkan tingkat profitabilitas perbankan.
\end{abstract}

Kata kunci: Perbankan Syariah, inflasi, Dana Pihak Ketiga, Pertumbuhan Ekonomi.

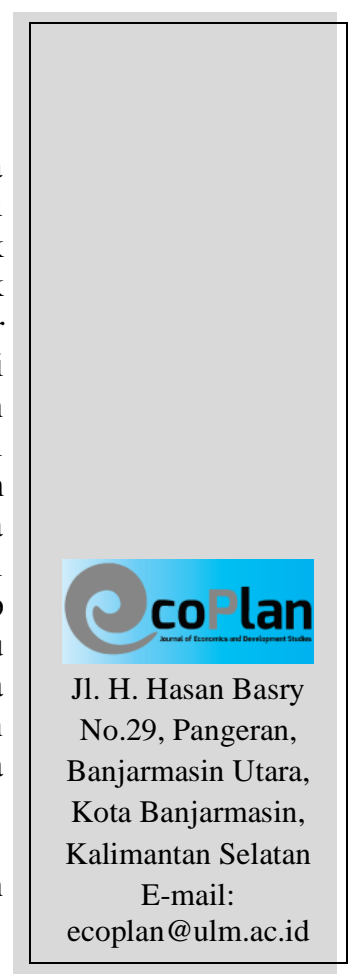




\section{PENDAHULUAN}

Fungsi perbankan sebagai lembaga keuangan dan intermediary memiliki peran penting bagi masyarakat. Perbankan dapat didefinisikan sebagai lembaga yang memiliki fungsi sebagai penghimpun dan penyalur dana dari dan kepada masyarakat (Kasmir, 2011). Peran penting perbankan tersebut membutuhkan adanya kegiatan operasional yang tepat dan sesuai dengan prinsipprinsip yang dianut masyarakat. Namun, pada kegiatan operasionalnya, kegiatan perbankan yang dijalankan secara konvensional selalu menggunakan sistem bunga. Hal ini menurut Qardhawi bahwa sistem bunga tersebut merupakan sesuatu praktik yang diharamkan dalam Islam (Wartoyo, 2010).

Permasalahan bunga pada perbankan konvensional mendapatkan perhatian serius dari cendekiawan Muslim di Indonesia. Oleh karenanya muncul gagasan baru untuk mendirikan perbankan yang tidak menggunakan prinsip bunga dalam kegiatan operasionalnya. Bank Syariah yang pertama kali berdiri di Indonesia yaitu Bank Muamalat Indonesia yaitu pada tahun 1992. Bank Syariah dapat didefinisikan sebagai perbankan yang menggunakan prinsip-prinsip syariah dalam melakukan kegiatan operasionalnya baik dalam usaha penyaluran dana maupun kegiatan jasa lalu lintas pembayaran (Muhammad, 2011).

Sebagai lembaga intermediary, perbankan memiliki kegiatan utama yaitu pembiayaan. Pembiayaan merupakan kegiatan perbankan berupa penyaluran dana kepada nasabah yang membutuhkan dengan berbagai syarat dan ketentuan yang dapat digunakan baik untuk kebutuhan konsumsi maupun investasi (Asfiyah, 2015). Berdasarkan beberapa penelitian yang telah dilakukan sebelumnya, diketahui bahwa terdapat beberapa faktor yang dapat mempengaruhi tingkat pembiayaan pada perbankan. Faktor internal bank yang dapat mempengaruhi pembiayaan yaitu DPK, SWBI, dan pendapatan bank; sedangkan faktor eksternal mampu mempengaruhi tingkat pembiayaan yaitu inflasi dan nilai tukar (Darma \& Rita, 2011). Selanjutnya juga ditemukan pada penelitian sebelumnya bahwa Return On Asset (ROA), Capital Adequacy Ratio (CAR), dan Dana Pihak Ketiga berdampak signifikan terhadap pembiayaan (Bakti, 2017).

Kegiatan operasional perbankan perlu selalu memperhatikan kondisi faktor eksternal seperti makro ekonomi sebab faktor eksternal tersebut sulit untuk dikontrol dan dapat mempengaruhi kinerja perbankan. Pertumbuhan ekonomi merupakan faktor makro ekonomi yang berpengaruh terhadap jalannya kegiatan operasional yang dilakukan oleh perbankan. Hal ini dikarenakan pertumbuhan ekonomi dapat menggambarkan kondisi rill tingkat kemakmuran yang terjadi pada masyarakat yang dinilai dari tingkat barang dan jasa yang diproduksi (Sukirno, 2017).

Penelitian ini menggunakan variabel moderasi yaitu pertumbuhan ekonomi dalam menganalisis hubungan yang terjadi antara inflasi dan Dana Pihak Ketiga terhadap pembiayaan. Kontribusi yang dapat diberikan penelitian ini yaitu memberikan analisis mengenai dampak yang dapat diberikan variabel pertumbuhan ekonomi dalam memoderasi hubungan yang terjadi antara inflasi dan Dana Pihak Ketiga (DPK) terhadap pembiayaan

Iinflasi memiliki pengaruh yang cukup besar terhadap perekonomian sebab menjadi tolak ukur adanya kenaikan harga. Pada dasarnya, inflasi dapat didefinisikan sebagai suatu proses kenaikan harga secara umum dalam suatu sistem perekonomian (Sukirno, 2017). Inflasi tidak hanya berdampak langsung terhadap masyarakat, namun juga dapat memberikan dampak terhadap perbankan. Menurut Dornbusch, Fischer, and Startz (2011) dampak inflasi terhadap perbankan dapat dijelaskan dengan menggunakan teori The Loanable Fund bahwa adanya inflasi dapat mengakibatkan adanya perubahan penggunaan uang seperti rendahnya minat untuk menabung, pengambilan dana secara masif di perbankan dan tingginya semangat untuk berbelanja dan lain sebagainya. Kondisi-kondisi inilah yang relatif mengakibatkan perbankan kesulitan dalam melakukan pembiayaan sebab dana yang terkumpul di perbankan semakin rendah.

Selanjutnya terkait dengan Dana Pihak Ketiga (DPK), Antonio memberikan definisi bahwa Dana Pihak Ketiga (DPK) merupakan kumpulan dana yang terkumpul di perbankan yang berasal dari dana-dana yang dihimpun dari nasabah (Fazriah et al., 2019). Dana Pihak Ketiga (DPK) memiliki peran penting bagi perbankan sebab pada kegiatan operasional, perbankan akan menyalurkan Dana Pihak Ketiga (DPK) tersebut kepada nasabah pembiayaan untuk memperoleh keuntungan. Semakin besar Dana Pihak Ketiga (DPK) yang terhimpun di perbankan, maka tingkat pembiayaan yang disalurkan perbankan juga akan semakin meningkat. Hal ini sebagaimana yang dijelaskan oleh Faizal dan Prabawa (2010) bahwa tingginya volume pembiayaan yang disalurkan sangat dipengaruhi oleh volume Dana Pihak Ketiga (DPK) yang mampu dihimpun oleh perbankan.

Pertumbuhan ekonomi dapat diukur dengan menggunakan proxy yang berbentuk bulanan yaitu Industrial Production Index (IPI). Industrial Production Index (IPI) merupakan sebuah indeks yang digunakan untuk mengukur jumlah output dari industri manufaktur, tambang, gas dan listrik yang dihitung menggunakan Fischer Index Formula. Tingkatan Industrial Production Index (IPI) dapat 
menjadi indikasi yang menjelaskan keadaan perekonomian dikarenakan indeks tersebut terkait dengan adanya penawaran dan permintaan di pasar barang dan jasa.

Pembahasan mengenai dampak inflasi, dan Dana Pihak Ketiga (DPK) terhadap pembiayaan telah dilakukan oleh beberapa penelitian terdahulu. Penelitian yang dilakukan oleh Ladime, SarpongKumankoma, \& Osei (2013), Ayieyo (2016), Agustinar (2014), Bakti (2017), Darma \& Rita (2011), Jamilah (2017), Prasasti \& Prasetiono (2014) dan Wardiantika \& Kusumaningtias (2014) menemukan bahwa variabel-variabel yang memiliki pengaruh yang signifikan terhadap pembiayaan yaitu bank size, struktur modal, suku bunga, nilai tukar, persaingan industri, Dana Pihak Ketiga (DPK), Non Performing Financing (NPF), Sertifikat Wadi'ah Bank Indonesia dan Surat Berharga Pasar Keuangan Syariah, Capital Adequacy Ratio (CAR), Return On Asset (ROA), BOPO, Financing to Deposit Ratio (FDR), spread, dan tingkat bagi hasil.

Penelitian ini memfokuskan menggunakan variabel inflasi dan Dana Pihak Ketiga (DPK) karena kedua variabel tersebut sangat terkait dengan tingkat pembiayaan yang disalurkan perbankan. Menurut teori The Loanable Fund, adanya inflasi dapat berdampak pada rendahnya minat menabung masyarakat dan dapat mengakibatkan pengambilan dana secara masif di perbankan (Dornbusch, Fischer, and Startz, 2011). Hal tersebut tentu dapat mempengaruhi kebijakan penyaluran yang dilakukan oleh perbankan. Kemudian, faktor Dana Pihak Ketiga (DPK) mengindikasikan bahwa tingginya volume pembiayaan yang disalurkan sangat dipengaruhi oleh volume Dana Pihak Ketiga (DPK) yang mampu dihimpun oleh perbankan (Faizal \& Prabawa, 2010). Hal inilah yang mendasari penulis untuk menggunakan variabel inflasi dan Dana Pihak Ketiga (DPK) sebagai variabel independen.

Berdasarkan pemaparan tersebut, kerangka teori yang dirumuskan pada penelitian ini yaitu:

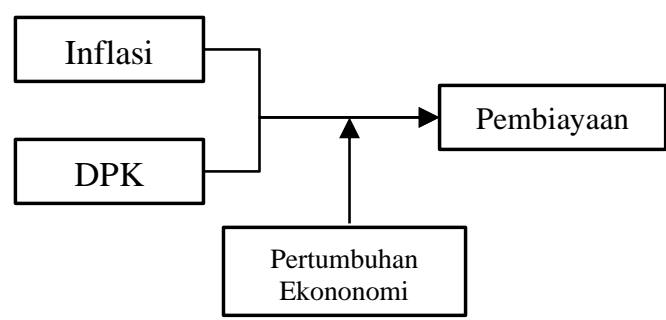

Gambar 1. Kerangka Teori
Penelitian menggunakan pendekatan kuantitatif dalam melakukan analisis. Data yang digunakan pada penelitian ini merupakan data yang berbentuk time series dengan periode Januari 2010 hingga Desember 2017. Data yang terkumpul merupakan data statistik yaitu data gabungan dari seluruh perbankan syariah di Indonesia, yang bersumber dari situs resmi BI dan BPS. Variabel yang digunakan pada penelitian ini yaitu:

Tabel 1. Variabel Penelitian

\begin{tabular}{|c|c|c|}
\hline Variabel & Definisi & Satuan \\
\hline Inflasi & $\begin{array}{l}\text { Indeks Harga } \\
\text { Konsumen } \\
\text { (IHK) }\end{array}$ & Persen \\
\hline DPK & $\begin{array}{l}\text { Giro, } \\
\text { tabungan, dan } \\
\text { deposito }\end{array}$ & $\begin{array}{l}\text { Rupiah (Rp) } \\
\text { yang dirubah } \\
\text { ke bentuk } \\
\text { logaritma } \\
\text { natural (ln). }\end{array}$ \\
\hline Pembiayaan & $\begin{array}{l}\text { Pembiayaan } \\
\text { yang } \\
\text { disalurkan }\end{array}$ & $\begin{array}{l}\text { Rupiah (Rp) } \\
\text { yang dirubah } \\
\text { ke bentuk } \\
\text { logaritma } \\
\text { natural (ln). }\end{array}$ \\
\hline $\begin{array}{l}\text { Pertumbuhan } \\
\text { ekonomi }\end{array}$ & $\begin{array}{l}\text { Industrial } \\
\text { Production } \\
\text { Index (IPI) }\end{array}$ & Persen \\
\hline
\end{tabular}

Guna menjawab pertanyaan penelitian, penelitian ini menggunakan teknik analisis data yang digunakan yaitu Error Correction Model (ECM), dengan model persamaan sebagai berikut:

DLPEM $_{\mathrm{t}} \quad=\beta_{0}+\beta_{1}$ DLINF $_{\mathrm{t}}+\beta_{2} \mathrm{DLDPK}_{\mathrm{t}}+$ $\beta_{3}$ DLINF*IPI $_{t}+\beta_{4}$ DLDPK $^{*}$ IPI $_{t}$ $+\mathrm{ECT}_{\mathrm{t}-1}+v_{t}$

ECT

$$
\begin{aligned}
= & \operatorname{DLINF}_{t}(-1)+\operatorname{DLDPK}_{t}(-1)+ \\
& \operatorname{DLINF}^{*} \operatorname{IPI}_{t}(-1)+\operatorname{DLDPK}^{*} \operatorname{IPI}_{t} \\
& (-1)
\end{aligned}
$$

Keterangan:

$\begin{array}{ll}\beta_{0} & =\text { Intersep } \\ \beta_{1-} \beta_{3} & =\text { Slope } \\ \text { INF } & =\text { Inflasi } \\ \text { DPK } & =\text { Dana Pihak Ketiga } \\ \text { PEMB } & =\text { Pembiayaan } \\ \text { IPI } & =\text { Industrial Production Index } \\ \text { IECT } & =\text { Error Correction Term } \\ v & =\text { Residual } \\ \mathrm{t} & =\text { Periode waktu jangka pendek } \\ \mathrm{t}(-1) & =\text { Periode waktu jangka panjang }\end{array}$

\section{HASIL DAN PEMBAHASAN}

\section{Analisis Deskriptif}

Berikut disajikan hasil analisis deskriptif variabel yang digunakan pada penelitian ini: 
Tabel 2. Analisis Deskriptif

\begin{tabular}{lrrrrr}
\hline \multicolumn{1}{c}{ Var } & Min & Max & Mean & Median & $\begin{array}{c}\text { Std. } \\
\text { Dev }\end{array}$ \\
\hline In_Pem & 31,5 & 33,3 & 32,6 & 32,8 & 0,5 \\
Inflasi & 2,8 & 8,8 & 5,2 & 4,6 & 1,6 \\
ln_DPK & 31,6 & 33,4 & 32,7 & 32,8 & 0,5 \\
IPI & 92,3 & 141,2 & 117,8 & 117,2 & 12,9 \\
\hline
\end{tabular}

Sumber: Data diolah (2020)

Berdasarkan tabel 2 tersebut, diketahui bahwa seluruh data pada periode observasi berada pada kondisi stabil karena selisih nilai antara mean dan median tidak terlalu jauh. Selain itu, data standar deviasi yang lebih kecil dibandingkan mean, menunjukkan bahwa simpangan data seluruh variabel adalah baik dan tidak memiliki data yang bernilai ekstrem.

\section{Uji Stasioneritas}

Hasil pengujian stasioneritas dengan menggunakan Augmented Dickey Fuller (ADF) dapat dilihat pada tabel berikut:

Tabel 3. Uji Stasioneritas

\begin{tabular}{|c|c|c|c|}
\hline \multirow{2}{*}{ Variabel } & \multicolumn{2}{|c|}{ Level } & \multirow{2}{*}{ Kesimpulan } \\
\hline & ADF & Prob & \\
\hline Pembiayaan & $-2,15$ & 0,23 & Tidak Stasioner \\
\hline Inflasi & $-2,68$ & 0,08 & Tidak Stasioner \\
\hline $\begin{array}{c}\text { Dana Pihak } \\
\text { Ketiga }\end{array}$ & $-2,83$ & 0,06 & Tidak Stasioner \\
\hline $\begin{array}{l}\text { Pertumbuhan } \\
\text { Ekonomi }\end{array}$ & $-0,66$ & 0,85 & Tidak Stasioner \\
\hline $\begin{array}{c}\text { Inflasi*Pertumbuh } \\
\text { an Ekonomi } \\
\text { Dana Pihak }\end{array}$ & $-2,79$ & 0,06 & Tidak Stasioner \\
\hline $\begin{array}{l}\text { Ketiga*Pertumbu } \\
\text { han Ekonomi }\end{array}$ & $-0,63$ & 0,86 & Tidak Stasioner \\
\hline
\end{tabular}

Sumber: Data diolah (2020)

Hasil pengujian tersebut menyimpulkan bahwa seluruh variabel yang digunakan tidak stasioner pada tingkatan level sehingga dapat disimpulkan bahwa variabel-variabel yang digunakan memiliki unit akar dan membutuhkan pengujian lanjutan untuk menentukan pada tingkatan derajat berapa variabel yang digunakan dapat stasioner.

\section{Uji Derajat Integrasi}

Setelah diketahui bahwa variabel yang digunakan pada penelitian ini tidak stasioner pada tingkat level, selanjutnya dilakukan pengujian derajat integrasi guna memperoleh gambaran lebih lanjut mengenai tingkat stasioneritas data.
Tabel 4. Uji Derajat Integrasi

\begin{tabular}{cccc}
\hline \multirow{2}{*}{ Variabel } & \multicolumn{2}{c}{ 1st Difference } & \multirow{2}{*}{ Kesimpulan } \\
\hline Pembiayaan & $-11,29$ & 0,00 & Stasioner \\
Inflasi & $-7,27$ & 0,00 & Stasioner \\
$\begin{array}{c}\text { Dana Pihak } \\
\text { Ketiga }\end{array}$ & $-9,60$ & 0,00 & Stasioner \\
$\begin{array}{c}\text { Pertumbuhan } \\
\text { Ekonomi }\end{array}$ & $-10,68$ & 0,00 & Stasioner \\
$\begin{array}{c}\text { Inflasi*Pertumbuh } \\
\text { an Ekonomi }\end{array}$ & $-7,75$ & 0,00 & Stasioner \\
$\begin{array}{c}\text { Dana Pihak } \\
\text { Ketiga*Pertumbu } \\
\text { han Ekonomi }\end{array}$ & $-10,72$ & 0,00 & Stasioner
\end{tabular}

Sumber: Data diolah (2020)

Hasil pengujian tersebut menemukan bahwa seluruh variabel yang digunakan dapat stasioner pada tingkat first difference. Hal ini mengindikasikan bahwa penelitian ini dapat dilanjutkan pada pengujian selanjutnya.

\section{Uji Kointegrasi}

Uji kointegrasi digunakan untuk mengetahui ada tidaknya hubungan jangka panjang diantara variabel-variabel yang digunakan. Berikut hasil pengujian kointegrasi:

Hasil pengujian ini menjelaskan bahwa terdapat koreksi hubungan jangka panjang diantara variabel penelitian ini yang terlihat dari tingkat signifikansi $5 \%$.

Tabel 5. Uji Kointegrasi

\begin{tabular}{cccc}
\hline & & $\mathrm{t}-$ Statistic & Prob.* \\
\cline { 4 - 4 } \multicolumn{2}{c}{ ADF test statistic } & $-7,26$ & 0,00 \\
\cline { 1 - 1 } Test & $1 \%$ level & $-3,50$ & \\
critical & $5 \%$ level & $-2,89$ & \\
values: & $10 \%$ level & $-2,58$ & \\
\hline Sumber: Data diolah $(2020)$ &
\end{tabular}

Sumber: Data diolah (2020)

\section{Analisis ECM}

Tabel 6. Pengujian ECM

\begin{tabular}{ccccc}
\hline Variable & Coeff & $\begin{array}{c}\text { Std. } \\
\text { Error }\end{array}$ & t-Statistic & Prob. \\
\hline C & 0,023 & 0,014 & 1,664 & 0,100 \\
D(INF) & 0,193 & 0,169 & 1,140 & 0,257 \\
D(LN_DPK) & 1,646 & 0,872 & 1,888 & 0,063 \\
D(IPI) & 0,179 & 0,168 & 1,061 & 0,292 \\
D(INF_Z) & $-0,002$ & 0,001 & $-1,181$ & 0,241 \\
D(LNDPK_Z) & $-0,017$ & 0,007 & $-2,379$ & 0,020 \\
\multicolumn{1}{c}{ ECT(-1) } & $-0,543$ & 0,093 & $-5,819$ & 0,000 \\
R-squared & 0,345 & & & \\
$\begin{array}{l}\text { Adjusted R- } \\
\text { squared }\end{array}$ & 0,267 & & & \\
$\begin{array}{l}\text { F-statistic } \\
\text { Prob(F- } \\
\text { statistic) }\end{array}$ & 4,422 & & & \\
\hline
\end{tabular}

Sumber: Data diolah (2020) 
Berdasarkan hasil penelitian, diketahui bahwa variabel ECT (Error Correction Term) memiliki tingkat signifikan dan bernilai negatif sehingga dapat disimpulkan bahwa model penelitian cukup baik dan memiliki koefisien koreksi kesalahan (Insukindro, dalam Manuhutu et al., 2014). Selanjutnya diperoleh bahwa koefisien ECT memiliki tingkat signifikansi $5 \%$ yang menunjukkan bahwa model penelitian ini valid dan dapat melakukan koreksi jangka panjang.

\section{Dampak Inflasi dan Dana Pihak Ketiga terhadap Pembiayaan}

Inflasi tidak memiliki pengaruh yang signifikan terhadap pembiayaan pada perbankan syariah dengan tingkat signifikansi 5\% (0,257 > 0,05). Karakteristik perbankan syariah yang menggunakan bagi hasil menjadi salah satu penyebab tidak signifikannya dampak yang diberikan inflasi. Kegiatan operasional yang dijalankan perbankan syariah bertumpu pada penerapan bagi hasil sehingga adanya inflasi tidak berdampak signifikan terhadap perbankan syariah. Pada saat terjadi inflasi, Bank Indonesia akan merespon dengan menaikan suku bunga agar terjadi perlambatan aktivitas ekonomi dan mengurangi dampak inflasi. Kenaikan suku bunga tersebut mengakibatkan masyarakat untuk menyimpan dananya di perbankan konvensional sehingga dampak inflasi akan lebih signifikan terhadap perbankan konvensional dibandingkan dengan perbankan syariah. Selain itu, laju inflasi yang terjadi di sepanjang periode observasi 2010-2017 menunjukkan bahwa tingkat inflasi yang terjadi sesuai dengan target yang telah ditentukan oleh Bank Indonesia. Hal ini mengakibatkan dampak inflasi yang terjadi terhadap perbankan tidaklah besar.

Hasil penelitian ini didukung dengan penelitian yang telah dilakukan sebelumnya bahwa inflasi tidak memiliki pengaruh yang signifikan terhadap pembiayaan perbankan (Hasanudin \& Prihatiningsih, 2010; Siswati, 2013)

Ditemukan pula Dana Pihak Ketiga (DPK) tidak memiliki pengaruh signifikan terhadap pembiayaan yang terlihat dari nilai signifikansi yang lebih besar dari 5\% $(0,06>0,05)$. Adanya kebijakan Bank Indonesia No.19/2/PBI/2017 yang mengatur tentang transaksi di pasar uang, mengakibatkan perbankan lebih nyaman dalam menyalurkan dananya di pasar uang. Hal ini dikarenakan adanya kemudahan dalam berinvestasi disertai rendahnya risiko yang ada, mengakibatkan perbankan lebih memilih menyalurkan dananya di pasar uang. Investasi di pasar uang tersebut dianggap lebih menguntungkan dibandingkan dengan melakukan peningkatan penyaluran pembiayaan.

Satria \& Subegti (2010) menjelaskan bahwa risiko penyaluran dana di sektor rill mengakibatkan perbankan menerapkan prinsip kehati-hatian dalam melakukan penyaluran pembiayaan. Perbankan mencoba menghindari risiko tersebut dengan mencari alternatif lain dalam menginvestasikan dana yang telah dihimpun yaitu dengan melakukan investasi jangka pendek di SBIS guna menjaga kepercayaan masyarkat terhadap perbankan.

Hasil penelitian ini sejalan dengan penelitian yang dilakukan oleh Setiawan \& Indriani (2016) dan Ovami \& Thohari (2018) bahwa Dana Pihak Ketiga (DPK) tidak berpengaruh secara signifikan terhadap penyaluran pembiayaan.

Peran pertumbuhan ekonomi dalam memoderasi hubungan yang terjadi antara inflasi dan Dana Pihak Ketiga hanya signifikan pada pengaruh Dana Pihak Ketiga terhadap pembiayaan dengan tingkat signifikansi 5\% dengan dampak negatif. Hal ini dikarenakan pada saat kondisi ekonomi sedang baik, Dana Pihak Ketiga (DPK) yang terdapat di perbankan syariah akan meningkat sebab banyak nasabah akan menginvestasikan dananya di perbankan syariah. Pada saat yang bersamaan, kondisi ekonomi tersebut juga akan menstimulus para nasabah untuk mengajukan pembiayaan. Namun hal tersebut tidak direspon secara langsung oleh perbankan syariah dengan segera menyalurkan banyak pembiayaan, akan tetapi perbankan syariah lebih bersikap hati-hati dan lebih selektif dalam menentukan nasabahnasabah yang layak memperoleh pembiayaan. Hal tersebut dilakukan agar perbankan syariah dapat meminimalkan adanya risiko gagal bayar.

Hubungan inflasi dan pembiayaan yang disalurkan perbankan syariah, pertumbuhan ekonomi tidak memberikan dampak moderasi yang signifikan. Hal ini dikarenakan kegiatan operasional yang dijalankan perbankan syariah bertumpu pada penerapan bagi hasil sehingga adanya inflasi tidak berdampak signifikan terhadap perbankan syariah.

\section{KESIMPULAN}

Inflasi tidak memiliki pengaruh yang signifikan terhadap pembiayaan pada perbankan syariah baik secara langsung maupun dengan adanya variabel moderasi pertumbuhan ekonomi. Hal ini diakibatkan oleh kegiatan operasional yang dijalankan perbankan syariah lebih bertumpu pada penerapan bagi hasil sehingga adanya inflasi tidak berdampak signifikan terhadap perbankan syariah.

Dana Pihak Ketiga (DPK) tidak memiliki pengaruh signifikan secara langsung terhadap pembiayaan, sedangkan dengan adanya variabel 
moderasi pertumbuhan ekonomi, ditemukan bahwa pertumbuhan ekonomi mampu memoderasi pengaruh yang diberikan Dana Pihak Ketiga (DPK) terhadap pembiayaan dengan arah yang negatif. Hal ini berarti pertumbuhan ekonomi mengakibatkan adanya pengaruh negatif yang diberikan Dana Pihak Ketiga (DPK) terhadap pembiayaan yang disalurkan perbankan syariah.

\section{DAFTAR PUSTAKA}

Agustinar. (2014). Analisis Pengaruh DPK, NPF, SWBI dan Surat Berharga Pasar Uang Syariah terhadap penyaluran Pembiayaan Perbankan Syariah di Indonesia ( Periode 2010-2014 ). Analytica Islamica, 5(2), 264 290.

Asfiyah, I. (2015). Implementasi Produk Pembiayaan Multijasa PT. BPRS PNMBINAMA Semarang. UIN Walisongo.

Ayieyo, J. O. (2016). Determinants Of Lending Behavior In Selected Commercial Banks In Kenya. International Journal of Economics, Commerce and Management, 14(9), 767782.

Bakti, N. S. (2017). Analisis DPK, CAR, ROA dan NPF Terhadap Pembiayaan pada Perbankan Syariah. Jurnal Bisnis \& Manajemen, 17(2), 15-28.

Darma, E. S., \& Rita. (2011). Faktor-Faktor Yang Berpengaruh Terhadap Tingkat Pengguliran Dana Bank Syariah. Jurnal Akuntansi Dan Investasi, 12(1), 72-87.

Dornbusch, R., Fischer, S., \& Startz, R. (2011). Makroekonomi, Edisi 11. Mc Graw-Hill.

Faizal, A., \& Prabawa, S. A. (2010). Analisis Pengaruh Total Aset, DanaPihak Ketiga dan Non Performing Financing terhadap Volume Pembiayaan Bagi Hasil. The Manager Review, 8(1), 65-72.

Fazriah, S., Sukmadilaga, H. C., \& Fitri, I. Y. (2019). Alternatif Penghimpunan Pendanaan Bank Syariah Melalui Program Wakaf Hasanah. Jurnal Ilmiah MEA (Manajemen, Ekonomi, \& Akuntansi), 3(3), 168-179.

Hasanudin, M., \& Prihatiningsih. (2010). Analisis Pengaruh Dana Pihak Ketiga, Tingkat Suku Bunga Kredit, Non Performance Loan (NPL), danTingkat Inflasi terhadap Penyaluran Kredit Bank Perkreditan Rakyat (BPR) di Jawa Tengah. Teknis, 5(1), 25-31.

Jamilah. (2017). Faktor-Faktor yang Mempengaruh Pengaruhi Pembiayaan Mudharabah pada Bank Umum Syariah di Indonesia. Jurnal Ilmu dan Riset Akuntansi. Jurnal Ekonomi Dan Riset Akutansi, 5(4), 1-20. https://doi.org/10.15408/etk.v16i1.4638
Kasmir. (2011). Manajemen Perbankan. Raja Grafindo Persada.

Ladime, J., Sarpong-Kumankoma, E., \& Osei, K. A. (2013). Determinants of Bank Lending Behaviour in Ghana. Journal of Economics and Sustainable Development, 4(17), 42-47.

Manuhutu, Y., Yoseph, F., \& Pauline, V. (2014). Keterbukaan Ekonomi Sektor Perikanan di Provinsi Maluku: Aplikasi Error Correction Model (ECM). Trikonomika Journal, 10(1), 63-71.

Muhammad. (2011). Manajemen Bank Syari'ah. UPP AMP YKPN.

Ovami, D. C., \& Thohari, A. A. (2018). Pengaruh Dana Pihak Ketiga dan Non Performing Financing terhadap Pembiayaan Musyarakah. Jurnal Penelitian Pendidikan Sosial Humaniora, 3(1), 298-304.

Prasasti, D., \& Prasetiono. (2014). Analisis Pengaruh Financing To Deposit Ratio, Non Performing Financing, Spread Bagi Hasil Dan Tingkat Bagi Hasil Terhadap Pembiayaan Bagi Hasil ( Studi Pada Bank Umum Syariah Di Indonesia Periode Tahun 2008-2013. Diponegoro Journal of Management, 4(4), 1-12.

Satria, D., \& Subegti, R. B. (2010). Determinasi Penyaluran Kredit Bank Umum Di Indonesia Periode 2006-2009. Jurnal Keuangan Dan Perbankan, 14(3), 415-424.

Setiawan, U. N. A., \& Indriani, A. (2016). Pengaruh Dana Pihak Ketiga (DPK), Capital Adequacy Ratio (CAR), dan Non Performing Financing (NPF) terhadap Profitabilitas Bank Syariah dengan Pembiayaan sebagai Variabel Intervening. Diponegoro Journal of Management, 5(4), 121-131.

Siswati. (2013). Analisis Penyaluran Dana Bank Syariah. Jurnal Dinamika Manajemen, 4(1), 82-92.

Sukirno, S. (2017). Ekonomi Pembangunan. Kencana.

Wardiantika, L., \& Kusumaningtias, R. (2014). Pengaruh DPK, CAR, NPF, dan SWBI terhadap Pembiayaan Murabahah pada Bank Umum Syariah Tahun 2008-2012. Jurnal Ilmu Manajemen, 2(4), 1550-1561.

Wartoyo, W. (2010). Bunga Bank: Abdullah Saeed vs Yusuf Qaradhawi (Sebuah Dialektika Pemikiran antara Kaum Modernis dengan Neo-Revivalis). Jurnal Fakultas Hukum UII, 4(1), 119-135. 